The World Journalism Education

Council (WJEC): Advancing global

Interaction Through Standards,

\title{
Teaching and Research
}

Goodman, Robyn S.

Foote, J., Goodman, R. S., Richards, I., \& Steyn, E. (2021). The World Journalism Education Council (WJEC): Advancing global Interaction Through Standards, Teaching and Research. Asia Pacific Media Educator, 31(2), 277-286. https://doi.org/10.1177/1326365X211056698 SAGE

https://doi.org/10.1177/1326365X211056698

https://uk.sagepub.com/en-gb/eur/posting-to-an-institutional-repository-green-open-access

This is the Accepted Manuscript of the following article: Foote, J., Goodman, R. S., Richards, I., \& Steyn, E. (2021). The World Journalism Education Council (WJEC): Advancing global Interaction Through Standards, Teaching and Research. Asia Pacific Media Educator, 31(2), 277-286, which has been published in final form at https://doi.org/10.1177/1326365X211056698. The article is protected by copyright and reuse of this Accepted Manuscript is restricted to non-commercial and no derivative uses.

Downloaded from AURA: Alfred University Research \& Archives 


\title{
The World Journalism Education Council - Advancing global interaction through standards, teaching and, research
}

\author{
Joe Foote, Robyn Goodman, Ian Richards \& Elanie Steyn
}

\section{WJEC history}

Journalism education, an academic field barely more than a century old in the West and much younger in other parts of the world, has focused primarily on its home turf and has attached itself to indigenous media. Only recently have there been global ambitions for the field. The $21^{\text {st }}$ century began with a mass proliferation of journalism programs around the globe. Factors like the opening of the Eastern bloc in Europe, privatization of media across Europe, the nascent recognition of journalism education as a university field beyond polytechnics in Europe, and the economic growth of Tiger and BRIC countries in Latin America and Asia all contributed to a new dynamic that made inter-country and inter-regional cooperation possible.

The growing wave of new or rapidly expanding programs created pressing needs for curricular materials, research outlets and support from the professional community. There was also a yearning to be recognized as a legitimate academic discipline. Organizations like the International Association for Media Communication Research (IAMCR) and the International Communication Association (ICA) were filling the need for a globally based outlet for communication research, but there was no global initiative focused exclusively on journalism education, especially the pedagogical elements. A 1997 UNESCO initiative called Journet had tried to fill that void but stalled when UNESCO funding ended.

The Association for Education in Journalism and Mass Communication (AEJMC), based in the United States, made its global foray into this space with back-to-back winter meetings in Mexico City (2001) and London (2002). The London meeting was a joint venture with the Association for Journalism Education (AJE) in the U.K. Both associations found this two-day meeting highly productive. An AEJMC Task Force on Internationalization (ITF) appointed by 
AEJMC President Joe Foote in 2001 and chaired by Dr. Dennis Davis convened a joint

AEJMC/AJE session at the London meeting to discuss the possibility of a more ambitious global meeting in the future. ${ }^{1}$ During this session, the task force's role began migrating from creating mechanisms within the AEJMC for international outreach to forging with other like-minded associations to create a one-time World Journalism Education Congress in 2007 (Foote, 2006).

A challenge was finding member organizations focusing on journalism education. The AEJMC task force found around one-half dozen organizations focused exclusively on journalism education and at least a dozen that considered it as part of their remit. With the addition of the Journalism Education Association of Australia in 2003, the newly formed group of three met in person in Kansas City, Missouri. The first major planning meeting was in Toronto in 2004 where eight of the 11 participating organizations from five continents (Asia, Europe, Africa, Oceania, and North America) were represented.

All were enthusiastic about a 2007 meeting, but paths diverged on its composition. Some saw the congress as an intimate meeting of the associations to discuss their mutual needs and to explore further collaboration. Others envisioned a massive, full-blown academic meeting attracting as many as 1,000 delegates. A breakthrough came when the delegate from the Asian Mass Communication and Information Centre (AMIC), a Singapore-based NGO that served both academic and professional constituencies (Foote, 2006), suggested a joint conference. Because AMIC was already mounting a major academic meeting in Singapore in 2007, this presented a fairly low-risk opportunity. Thus, by the end of the Toronto meeting, the movement had a constituency and a venue for its upcoming meeting. The delegates were pleased because Singapore met all their criteria: it was a major city venue outside the U.S. and Europe with excellent infrastructure and transportation gateways, it was located proximately to a large concentration of journalism education programs, and the host had a secretariat and a long

\footnotetext{
${ }^{1}$ Dr. Dennis Davis of Penn State University played an instrumental role in the formation of WJEC. His task force report was the catalyst that propelled a series of later planning meetings for the 2007 Congress and dispelled AEJMC's aspirations of creating a parallel international organization. Dr. Davis was also a co-author with Joe Foote of the Declaration of Journalism Education Principles that was ratified at the first World Journalism Education Council meeting in Singapore. Dr. Robyn Goodman from Alfred University was an original member of the AEJMC task force and remains an active leader in WJEC today along with Foote.
} 
history with convention planning. There would be opportunity for both an association meeting and a full-scale congress.

With nearly three years to plan the meeting, the group focused on programming and expanding its ranks. By a 2005 planning meeting in San Antonio, Texas, the WJEC planning group had grown to 15 organizations with associations from China, South Korea, and South America being important additions, as well as Journet (Foote, 2006). The Knight Foundation funded a global census of journalism education that would be completed by the 2010 (see below) and a working group began drafting a Statement of Principles for Journalism Education that, hopefully, would be s guiding light for the elevation of journalism education's purpose and status. Overall, the goals WJEC was hoping to achieve with the 2007 conference were (Foote, 2006):

- Global recognition and understanding of the field

- $\quad$ Clearer definition of the field

- $\quad$ Opportunity to share teaching materials and scholarship

- A catalyst for exchange between countries

- A mechanism for continued collaboration among associations and scholars.

Multiple issues were swirling around journalism education. This was a time when academic programs in the West were frantically trying to converge their siloed programs as the lines between media were being blurred and increasing value was placed on cross-training and breadth rather than depth. Even administrators who were leaning into convergence were struggling to keep the depth and quality of their existing programs while trying to add crossmedia options. Meanwhile, many developing countries were still facing the challenge of transitioning from a theory-based academic program to a laboratory-based program providing practical skills as well as conceptual content. Most lacked the resources to establish laboratories and the faculty qualified to run them.

The academic/professional relationship was a universal problem, but it was manifesting itself in significantly different ways. Most developing country academic programs found themselves estranged from their professional counterparts. Many news managers avoided 
hiring university-trained journalism graduates and bragged of having to "unlearn" bad habits among the ones they did hire. Adjuncts from the profession, internships in news organizations, and professional advisory boards were rare. Meanwhile, programs in some of the oldest journalism programs in the West were seeing closer relationships develop between the academy and the profession after years of adversarial bickering. The convergence revolution and the belt tightening among news organizations had made academic relationships more appealing and productive. In many cases, the supplicants were the professionals rather than the academics.

A third area of concern was the status of journalism education within the university. Some programs were fighting to elevate from polytechnic to the university level or to achieve some autonomy within a broader department of communication. Older, more established programs were aspiring to be free-standing units under the direction of a dean. Journalism educators were realizing that they had become self-isolated within the broader academy with few power strings to pull and little respect from their peers. The Declaration of Principles for Journalism Education, which the WJEC planning group had been working on, was designed to advance the status of the field, with the primary audience being top university administrators and governmental oversight bodies.

A fourth area was quality control in journalism education. What criteria does one use to evaluate quality in a program? How can parents and students tell a superior program from an ordinary one? What kind of self-reflection and total quality improvement measures do faculty and administrators take to improve quality? In this area, WJEC would find a patchwork of governmental oversight programs, accreditation initiatives, and industry-based approaches.

Finally, journalism educators were starting to perceive a responsibility not only to educate future journalists, but to also increase the audience's media literacy. Some programs were realizing that reaching out beyond their narrow academic borders to a university-wide audience was an avenue to increased status and responsibility within the academy.

All these issues were a reality in journalism education when the World Journalism Education Congress convened in Singapore in July 2007. Some 500 delegates from 45 nations 
attended, although more than 300 of them were there primarily for the AMIC meeting (Foote, 2008). Each group maintained its own programming strands, but each session was open to the other. Several AMIC delegates sampled WJEC sessions, which were usually filled to capacity.

The WJEC congress had four programming bands: plenary sessions, program sessions, research competition sessions and small group syndicates. UNESCO used one of the plenaries to unveil its training centers of excellence in Africa and the model curriculum it had written for these centers.

The Syndicate Program is a unique feature of WJEC, devised by an Australian association delegate, Sue Ellen Tapsall, during earlier planning sessions. The syndicates (see below) featured a three-day small group experience that explored a problem and reported back at a closing plenary. This element mixed nationalities and brought major issues down to a small group environment. After Singapore, the consensus was that while the issues facing journalism education were mostly universal, the perspectives and solutions were not. Each participating country had unique content and perspectives to contribute.

The day before the WJEC/AMIC conference began, the organizations that were involved in the planning of the conference met. The group approved the "Declaration of Principles of Journalism Education" (WJEC, 2021) and formed themselves into a World Journalism Education Council. While the Singapore meeting was planned as a one-time event, the association delegates overwhelmingly believed that these efforts should be continued through a permanent semi-formal organization. By the time the Singapore meeting ended, the organizing group had grown to 28 organizations (Foote, 2008; see Table 1).

While there was no set date for the second WJEC, the delegates leaving Singapore felt there definitely should be one. The uncertainty vanished during a 2009 Council planning meeting in Boston, Massachusetts, when Rhodes University in Grahamstown, South Africa, through its head, Guy Berger, volunteered to host the second WJEC the following year. Given that the first WJEC had taken five years to organize, the leadership was taken off guard by the short time frame. Yet, the Council delegates were enthusiastic about this proposal and eager to move forward (Foote, 2011). 
Unlike Singapore, the Grahamstown congress would see WJEC standing on its own without the safety net of another academic associations meeting with it. The 2010 planners set the date in conjunction with Highway Africa, which they hosted for professional broadcasters. Thus, the Rhodes University campus was packed with delegates from both meetings. Each met separately but came together for major luncheon speakers and evening social events. Archbishop Desmond Tutu headlined the closing event.

It became evident in Grahamstown that a key feature of WJEC conferences would be their regional backbones. African academics turned out in force for the 2010 meeting, creating a stimulating, refreshing environment. Delegations from countries like Ghana were incredibly excited to be presenting research before an international body with delegates from nearly 50 nations. Likewise, this was a rare opportunity for delegates from Europe and the Americas to interact with African colleagues. This trend would continue as each WJEC put its own regional stamp on the conference.

By the 2010 congress, the WJEC Council realized there should be a set schedule for meetings. Delegates decided on a three-year interval and solicited bids by organizations wishing to sponsor a meeting. Following that protocol, the Council met in Istanbul, Turkey, in 2011 to choose the European Journalism Education Association as its partner and Mechelen, Belgium, as the location for the 2013 congress. Subsequently, the Council would choose Auckland, New Zealand (2016), Paris, France (2019) and Beijing/Shanghai, China (2022).

The Paris congress in 2019 attracted 600 delegates from 70 countries, the largest WJEC turnout. The Paris organizers added a student element to the congress format that brought five students from five continents to Paris to participate in a variety of panels and syndicates. The Council also issued a Paris Declaration (Declaration of Principles of Journalism Freedom) that expanded and augmented the 2007 document. $^{2}$ The Council felt that periodic declarations concerning pressing issues or ideals were one of the ongoing contributions the Council could make to the field.

\footnotetext{
${ }^{2}$ Dr. Pascal Guénée, the organizer of the Paris WJEC, was the principal author of this second WJEC declaration.
} 
The Paris Congress also marked the approval and inauguration of a charter to govern the Council. With the World Journalism Education Council on firm footing and its triennial congresses running successfully, the WJEC Steering Committee pushed for a firmer organizational framework for the Council. In the interval between Auckland and Paris, the steering committee proposed a charter to allow for a democratic election of leadership and expanded ground rules for membership in the Council. Long-time Council member Dr. Kaarle Nordenstreng from Finland, along with other colleagues, advocated for a formal governing document. After a year's debate that balanced formality, bureaucracy, flexibility, and efficiency, the Council approved the charter in Paris. The leadership transitioned from founding chair Dr. Joe Foote of the United States to Dr. Verica Rupar of New Zealand, its first elected leader. Through this process, the Council strengthened the bones of the organization without imposing a heavy bureaucratic structure or requiring membership dues.

From its nascent days at the turn of the $21^{\text {st }}$ century, the WJEC operated as an informal consortium of organizations guided by a consensus of how it would move forward from year to year. Particularly compelling about the WJEC movement has been its informal, voluntary, and self-supporting character. What started as a few associations talking with each other has developed organically into a structure that encompasses countries on every continent. Organizations came together under their own funding to interact with colleagues, discuss common issues, and form an umbrella organization that could help their own members as well as the field in general. Today, this collection of volunteer Council delegates with no secretariat and no budget has coalesced into a formidable body that is developing an agenda beyond holding triennial congresses and is making a significant global impact.

Three of the most salient focuses of the organization are discussed below: the Principles in Journalism Education, its focus on the teaching of journalism and journalism research.

\section{Declaration of Principles in Journalism Education}

One of the great successes of the first WJEC gathering in Singapore in 2007 was the world's first "Declaration of Principles in Journalism Education" (World Journalism Education 
Council, 2007). To appreciate the significance of this Declaration, it is useful to go back more than a century to the time when prominent U.S. publisher and journalist Joseph Pulitzer predicted that, before the end of the $20^{\text {th }}$ century, "schools of journalism will generally be accepted as a feature of specialized higher education like schools of law and medicine" (Pulitzer, 1904, p. 20). Pulitzer was a driving force behind the creation of the journalism program at Columbia University in New York, and, by any yardstick, that program has been highly successful. But despite this, and despite the dramatic expansion of university journalism courses around the world during the second half of the $20^{\text {th }}$ century, things have not worked out quite as Pulitzer predicted. For what G. Stuart Adam called "the project of journalism education" has failed to produce "a professional discipline of great prestige and the field does not possess the levels of legitimacy marking schools of law, medicine, engineering, or even business" (Adam, 2001, p. 315).

There are many reasons for this, some of which can be traced back to the historical forces which shaped the development of journalism in the first place. These include the commercial context in which most journalism was published historically; the intensely practical nature of many journalism courses at the time they were introduced into the academy; and the persistence of a view among many practitioners that journalism is a craft or trade not suited to university level instruction. The situation was not helped by the fact that conventional models of the professions proved inappropriate to journalism. This is partly because journalism lacks clearly defined "clients," but primarily because of the close and fundamental relationship between the practice of journalism and the principles of freedom of speech and expression. To preserve this relationship, so central to the functioning of democratic society, journalists have strongly resisted the types of official regulation and registration that are the hallmark of most professions.

But while such factors have all played a part, one of the most significant reasons for journalism's failure to realize Pulitzer's prediction is simply that those who teach journalism have "mainly failed as a professional group to express adequately their professional and pedagogical tasks" (Adam, 2001, p. 15). This failure helps explain why the 2007 Singapore Congress of the WJEC made a concerted effort to reach agreement on the key principles 
underlying and guiding journalism education around much of the globe. While the declaration was not solely devoted to promoting journalism education as an academic discipline, much of its content was designed to help achieve that end.

The signing of the declaration was preceded by an extended discussion among delegates during which it became clear that, while they shared common values, achieving unanimous agreement to a written set of principles would not be easy. Some argued that no matter how skillfully worded, no set of principles could guarantee all signatories would always adhere to them, while others maintained that any list of principles would prove to be "unworkable" unless it included penalties for breaches. Others were concerned that any declaration would amount to little more than window-dressing to placate critics among the wider public. Against such views, it was argued that a declaration of principles would provide a public expression of the common values and ideals held by those engaged in journalism education and research around the world. It would play an important symbolic role for those working in the area and serve as a reminder to outsiders of the central role played by the common activity in which journalism educators are engaged. In doing so, a declaration would help journalism education's efforts for university management and government administrators to accept it as a serious discipline. At an immediately practical level, it would lend strength to the case for journalism academics to be given the same opportunities as academic colleagues in more traditional disciplines. Finally, a declaration of principles would provide an international "yardstick" for assessing the qualities and performance of an important emerging discipline.

Despite their differences, the Singapore delegates agreed upon a carefully considered document which gave a clear exposition of what journalism education is - or should aim to be. Foote (2008, pp. 135-6) listed the key points in the Declaration of Principles in Journalism Education as follows:

1. At the heart of journalism education is a balance of conceptual, philosophical and skillsbased content. While it is also interdisciplinary, journalism education is an academic field in its own right with a distinctive body of knowledge and theory.

2. Journalism is a field appropriate for university study from undergraduate to postgraduate levels. Journalism programs offer a full range of academic degrees 
including bachelors, masters and Doctor of Philosophy degrees as well as certificate, specialized and mid-career training.

3. Journalism educators should be a blend of academics and practitioners; it is important that educators have experience working as journalists.

4. Journalism curriculum includes a variety of skills courses and the study of journalism ethics, history, media structures/institutions at national and international level, critical analysis of media content and journalism as a profession. It includes coursework on the social, political and cultural role of media in society and sometimes includes coursework dealing with media management and economics. In some countries, journalism education includes allied fields like public relations, advertising, and broadcast production.

5. Journalism educators have an important outreach mission to promote media literacy among the public generally and within their academic institutions specifically.

6. Journalism program graduates should be prepared to work as highly informed, strongly committed practitioners who have high ethical principles and are able to fulfill the public interest obligations that are central to their work.

7. Most undergraduate and many master's programs in journalism have a strong vocational orientation. In these programs experiential learning, provided by classroom laboratories and on-the-job internships, is a key component.

8. Journalism educators should maintain strong links to media industries. They should critically reflect on industry practices and offer advice to industry based on this reflection.

9. Journalism is a technologically intensive field. Practitioners will need to master a variety of computer-based tools. Where practical, journalism education provides an orientation to these tools.

10. Journalism is a global endeavor; journalism students should learn that despite political and cultural differences, they share important values and professional goals with peers in other nations. Where practical, journalism education provides students with firsthand experience of the way that journalism is practiced in other nations. 
11. Journalism educators have an obligation to collaborate with colleagues worldwide to provide assistance and support so that journalism education can gain strength as an academic discipline and play a more effective role in helping journalism to reach its full potential.

The central themes contained in the Declaration of Principles in Journalism Education were further refined in the four subsequent WJEC gatherings. During this time journalism educators found themselves buffeted by the same disruptive forces affecting the practice of journalism around the globe - the rise of social media, increasing attacks from governments, and the demise of the business model which had supported legacy media for decades. The impact of these forces dominated many of the discussions at the various WJEC congresses, although it was apparent to those attending that there was an increasing discrepancy "between the sad state of the mainstream media and their struggle to survive and the blossoming of journalism forms and practices at the fringes of the journalism field" (Rupar, 2016, p. 295). As time went on, it also became clear that, in a time of constant flux and dramatic change, journalism education needed something more than the Declaration of Principles.

At the Paris Congress in 2019, this sentiment culminated in delegates drafting a broader document and, on July 10, 2019, the "Paris Declaration on Freedom of Journalism Education" was formally signed by the Chairperson of WJEC Paris, Pascal Guénée of IPJ Dauphine, and the President of WJEC, Joe Foote, in the presence of the Deputy Mayor of Paris, Marie-Christine Lemardeley, and the President of the Université Paris-Dauphine, Isabelle Huault (World Journalism Education Council, 2019). Briefly, the document reiterated and strengthened a number of the principles raised in the 2007 declaration and also extended the list with additional points. These included the need to maintain strong and independent governance of journalism schools and journalism departments; preserve journalism education as a distinctive stream; mobilize the necessary funding as required for the quality functioning of journalism schools; and balance the requirements for academic knowledge with the technical skills of journalism. Current WJEC Chair Verica Rupar has summarized the central themes of the Declaration as follows (Rupar, 2020):

- $\quad$ quality of journalism and quality of journalism education; 
- quality of journalism education and the quality of information;

- journalism education and inclusivity;

- journalism education and diversity;

- journalism education and UN Sustainable Development Goals; and

- journalism education and disinformation, misinformation and the threats to press freedom.

The document incorporated a call for support for these principles from the following key groups: journalism educators and trainers around the globe; leaders in higher education and training NGOs; national departments of education, media industries, private businesses, and donors; and UNESCO's International Program for the Development of Communication (IPDC), which was also asked to bring the Declaration to the attention of UNESCO member states.

The request to approach UNESCO was the WJEC's acknowledgement of the impressive work done by that organization in relation to journalism education and training over the previous two decades. UNESCO clearly demonstrated its strong commitment to this field by its "Series on Journalism Education," which resulted in a range of model curricula in various formats and languages that could be applied in journalism programs around the world. As the division of the United Nations responsible for education, the sciences, and culture, UNESCO has long recognized that high journalistic standards are necessary "to bring out the potential of media systems to foster democracy, dialogue and development" (UNESCO, 2019). And, as WJEC members have long recognized, high standards of journalism education are necessary if new entrants are to be equipped to produce journalism that is genuinely capable of fostering democracy, dialogue, and development. Given that the WJEC's overall objective is to "enhance the quality of journalism and media" (WJEC, 2007), and given that it occupies a genuinely global position in the field of journalism education, the case for working more closely with an organization like UNESCO is obvious.

In late 2020, the International Program for the Development of Communication formally recognized the Paris Declaration. (IPDC is UNESCO's main forum for promoting media 
discussion and development in member states, especially those located in the Global South) This formal recognition underlines the international credibility of the Declaration while at the same time acknowledging the vital role the WJEC plays globally. The IPDC's positive response also increases the likelihood of a closer working relationship between the WJEC and UNESCO.

Despite the ravages of the Covid-19 pandemic, there is an underlying sense of optimism among journalism educators about the future. Although it is too soon to say what form or direction WJEC's interaction with UNESCO might take, it has been suggested that co-operation between the two organizations could lead to new curricula for journalism programs dealing with such issues as how to report on Artificial Intelligence, how to advance sustainable development, and how to negotiate with "powerful actors, superiors, crowds, sources and others, so as to further professional and safe reporting" (IPDC, 2019). After its first congress in 2007, then chair Joe Foote said that the congress had produced "a foundation of trust and respect that will yield longer-term benefits" (Foote, 2008, p. 137). A decade and a half later, developments such as the Paris Declaration and the IPDC response to it demonstrate just how prescient his comments were.

\section{Advancing global interaction through research}

While curriculum, pedagogy and social responsibility issues have dominated WJEC, research has been a significant component. One of the main objectives of the first World Journalism Education Congress in Singapore in 2007 was to establish a forum through which international scholars and practitioners can share research (see Asia Research News, 2007). During this conference, that stretched over a period of four days, educators and students participated in plenary sessions that focused on topics related to the state of the field of journalism, journalistic freedom and responsibility, and comparative models of journalism education. In addition, sessions also included panels and research presentations related to pedagogy, research trends, and critical professional issues (Asia Research News, 2007).

As the organization developed and matured over the next decade and a half, its goals toward advancing global interaction through research manifested in the specific focus areas discussed below. 


\section{Research panels and paper presentations at congresses internationally}

Not only was it a goal of the WJEC as an organization to host its conference in a different part of the world every three years (to move away from any assumptions that Western perspectives are somehow superior to those perspectives from elsewhere in the world), but it was also concerned to attract the perspectives and voices of as diverse an audience as possible in regard to panel topics/sessions and research. One way to achieve this was to collaborate with a local journalism education institution/organization each time a conference was scheduled. During the first conference in Singapore, for instance, partnership with the Asian Media Information Center (AMIC) resulted in nearly 500 delegates from 44 countries attending the event (see Foote, 2007; also see above). Similarly, by collaborating with the organizers of the Highway Africa conference at Rhodes University in South Africa in 2010, the event attracted close to 400 delegates, many of whom included "journalists from a continent that generally remains marginalized internationally" (Rhodes University, 2010). This gathering of journalism educators from across the globe provided an opportunity to "cross-pollinate experiences and to brainstorm ways in which to take forward the relevance of the practice around the globe" (Rhodes University, 2010). In addition, events at the conference were made accessible to an even more inclusive audience since collaboration with and a sponsorship from Hanban, a Chinese cultural institute, resulted in conference proceedings being made available in Mandarin (Bizcommunity, 2010), while the conference was streamed live on the WJEC website and covered by several radio and television partners in South Africa.

Because of increased awareness of, and growing interest in, the WJEC as an organization, with each conference, the WJEC organizers (in collaboration with the host country organizers) were able to expand on both the number and diversity of research paper presentations. Similarly, they expanded the scope of topics covered in the presentations as well. The goal, as mentioned above, was to have as much of an inclusive look into the journalism and journalism education topics relevant to professionals and academics from across the world. From the outset, paper submissions went through a double-blind peerreviewed process, and reviewers were represented from different countries of the world as well. In addition, the AEJMC supported the top three research papers with a small financial 
incentive during each conference. This gesture demonstrated their support for the conference and the academic rigor of research presented at the conference.

Two examples of how research presentations and panels at the WJEC conferences have contributed to adding a collaborative and international perspective to research in the field of journalism was through research panels focusing on the "Worlds of Journalism Study" at the 2016 conference in Auckland, New Zealand, and research sessions on "Journalistic roles, values and qualifications in the $21^{\text {st }}$ century" at the 2019 conference in Paris (see WJEC, 2020). Whereas the first project focuses on insights into how professional journalists from 67 countries view their roles and responsibilities in society (see Worlds of Journalism, 2020), the second highlights how European journalism educators see the future of journalism and journalism education. By including international research projects like these into conference sessions at different WJEC conferences, journalists and journalism educators from across the world get an opportunity to connect and exchange ideas and insights on research results that either correlate or differ internationally.

\section{Global journalism education in the $21^{\text {st }}$ century: Challenges and innovations}

In addition to paper sessions and published proceedings of WJEC congresses, members have initiated major projects that survey the field in print and provide fresh views on how journalism education is progressing around the world. Veteran WJEC leaders, Robyn Goodman and Elanie Steyn in 2017 produced an academic volume that grew "out of the series of threeyearly global gatherings" (Baines, 2017). Global journalism education in the $21^{\text {st }}$ century: Challenges and innovations (Goodman \& Steyn, 2017). It was the result of collaboration and exchange between journalism educators and practitioners from around the world (see Fidalgo, 2018). Baines (2017) described it as "a fine blend of scholarship, expertise, insight and innovation from journalism educators in all corners of the globe." The idea with the volume was to provide a "practical/approachable reference book for educators, trainers, journalists, media activists, policymakers, foundations, non-government organizations, students, and others with a vested interest in quality journalism" (Goodman \& Steyn, 2017). 
Collaborating with the Knight Center for Journalism in the Americas at the University of Texas in Austin, the editors published both a hard copy and a free online version of the book. It was translated into Spanish in 2018. The volume consists of reflections on journalism education across 10 different countries, as well as a section that contextualizes journalism education and a final section that focuses on modern-day initiatives journalism educators are taking to reflect and address "the complexity in our teaching and in our curricula, wherever our students hail from" (Baines, 2017).

As Claussen (2017, p. 108) puts it, one valuable contribution of the book, from a global insight perspective, is that "each country's journalism education has one or more problems ... that is, or soon could, severely retard its quality and progress." This shows that, irrespective of where journalism education is located, the constantly changing nature and high level of uncertainty about the future of journalism affects the possibilities and outcomes of educational efforts. It also shows, however, that journalism educators across the globe have found ways to address these challenges - examples that could provide valuable insight and ideas for programs and countries facing similar challenges.

\section{WJEC Census}

One of the first, and probably most ambitious, research endeavors of the WJEC was the WJEC Census (WJEC, 2019). The global census, funded by the Knight Foundation and implemented by the Institute for Research and Training (IRT) at the University of Oklahoma's Gaylord College, aimed to "assemble the first ever census of journalism education around the world ... to try identify every journalism program that could be found and to assemble basic contact information for each program" (Self, 2007, p. 8). Ultimately, it endeavored to be a tool that would "help journalism educators find institutional partners and further their programs' research aims" (PND, 2010).

By the time the first WJEC congress was held in Singapore (see above), the census had collected and listed names and contact information for close to 2,000 journalism education programs worldwide (Self, 2007, p. 9). That number quickly increased to close to 2,500 in the 
Fall of that year, including close to 700 programs in North America, about 650 in Asia, 530 in Europe, just over 200 in Africa and South America respectively and 53 in Oceania (PND, 2010). Updating the WJEC Census is a research endeavor on the Council's agenda because getting an accurate view of where colleagues are operating around the world is important to understanding the growth, movement and status of the field.

\section{Syndicate Primacy}

Another important part of WJEC's research program is real-time research that results from robust, sustained structured conversations over several days. Of all WJEC's activities during the last 15 years, the Syndicate Program seems to represent its most consistent, small group/intimate, interpersonal, research-backed discussions regarding how to best approach the ultimate global journalism education curriculum. (The program offers about a dozen syndicates, triennially, dealing with journalism education topics;

From Singapore to Paris, all syndicate programs have explored and discussed some version of the following (Goodman, 2020, p. 5):

- $\quad$ journalism in a digital age, the need for increasing diversity and inclusion;

- $\quad$ protecting different viewpoints during increased media consolidation and globalization;

- $\quad$ examining quality control in journalism education

- $\quad$ improving journalism education's status in the academy;

- $\quad$ exploring the state of journalism research; and

- $\quad$ creating the ultimate journalism education.

Although all of these topics are important, tracing the specific ultimate journalism education syndicate sessions ${ }^{3}$ offer insight into how the global community has imagined the

\footnotetext{
${ }^{3}$ The Auckland and Paris conferences did not have syndicate groups specifically focused on the ultimate journalism education. Accordingly, their approaches to this gold standard were traced, in a bricolage manner, from their related syndicates and conference programming.
} 
ultimate curriculum over time and the WJEC's help influencing it via passionate involvement in the process.

Singapore (2007): The Singapore conference's ultimate journalism education syndicate, like Singapore's Declaration of Principles, focused heavily on building a curriculum that addressed straight-on the academic/professional balancing act and the need to recalibrate the scale to favor a more academic approach. Simultaneously, it focused on beefing up educators' professional skills and media outreach (Goodman, 2007). This newly enriched, comprehensive academic approach called for more rigorous critical analysis of media content and reflection on the role of journalism in society, with an emphasis on ethics and social responsibility throughout the curriculum. It also emphasized the need for building up, and teaching, journalism's scholarly body of knowledge to offer a more informed view of journalism for future practitioners and to better establish journalism education as an academic field in its own right. Finally, it argued this gold standard curriculum must be global in scope, with an emphasis on shared global values and professional goals.

Grahamstown, South Africa (2010): Like the corresponding Singapore syndicate, Grahamstown's emphasized the need to tip the curriculum toward a more academic (and global) perspective while still keeping up with rapidly evolving professional skills (Goodman, 2011). Grahamstown added that a truly integrative academic perspective that could not be achieved without first reframing the purpose/goal of a journalism curriculum in a more public service-oriented, social responsibility manner than a career-oriented one. The discussions also highlighted the importance of holding those in power accountable and consistently advocating for free, independent expression. Finally, they further emphasized the need to teach future journalists, throughout the curriculum, to effectively engage in participatory journalism in hopes of further empowering individuals and communities.

Mechelen, Belgium (2013): Global journalism education scholar Mark Deuze (2017) passionately argued during a keynote speech in Mechelen that educators, once and for all, must decide whether they are training journalism students to be "super citizens" or for future industry careers. Although journalism educators likely prefer both options, Deuze insisted a decision must be made. Deuze (2017) described his paradigm as one in which journalists - 
armed with fine-tuned critical, reflective, and inclusivity skills along with a deep understanding of the networked information age - passionately, ideally with community help and/or buy-in, pursue and deliver quality information most useful to citizens. The Ultimate Journalism Education syndicate, taking Deuze's lead, seemed focused on accelerating this approach by encouraging a pro-active, super citizen-type curriculum stressing global human values, inclusivity, and community teamwork. The syndicate stressed an urgent need to fill the curriculum with global perspectives, truth-seeking, and citizen/civic journalism-related knowledge and skills, along with advocating for educational partnerships with industry to protect journalism at large.

Auckland, New Zealand (2016): Auckland conference discussions did not focus as much on reframing the curriculum via a super citizen model (Goodman, 2017c). However, its curriculum recommendations certainly had this perspective in mind. In addition, Auckland, while generally agreeing with previous conference recommendations, emphasized teaching news literacy skills for future journalists - including how to effectively verify facts, navigate fake news, and transparently cover stories. It also encouraged inclusive community engagement and public service. Furthermore, it emphasized the curriculum's need to keep up with technology, effectively teach transmedia storytelling via mobile platforms and social media, and the value of both experiential university-based (i.e., teaching hospital model) and industry-based learning.

Paris, France (2019): Paris, like Auckland, appeared to support and build on most previous WJEC ultimate journalism education curriculum findings and recommendations. Instead of focusing on re-conceptualizing the curriculum, Paris delegates concentrated on the curriculum's need to more rigorously and comprehensively teach super citizen-type knowledge and skills (Goodman, 2020). For example, discussions in Paris emphasized that higher quality inclusivity training is needed to ultimately help build more cohesive, productive societies. And to accomplish this goal, the curriculum needs to help students dig deeper into their own stereotypes and biases. Paris delegates argued such reflection will help students more effectively reach out to all types of diverse individuals and communities, within and among regions and nations, in all stages of their reporting. Another curriculum necessity: monitoring, 
safeguarding and/or promoting journalism's need for independence and its support for democratic institutions.

The WJEC's ultimate journalism education and related syndicates will continue pushing for curricular innovation and trends, especially weighing in on the the balance between conceptual and societal teaching and those related to skills.

\section{Conclusion}

With two decades of experience behind it, the World Journalism Education Congresses have become solid touchstones for international cooperation and integration. The triennial congresses have trained their spotlights on several regions of the world and have promoted a unique brand of broad-based sharing, innovation and comradery. Through WJEC's constant format elements, the progress and problems of journalism education over time have become more focused, transparent and seriously studied. Through the efforts of the World Journalism Education Council, proclamations like those issued in Singapore and Paris have served as a standard for the field and what it aspires to be.

Having successfully executed so many congresses, WJEC now aspires to serve educators who may never attend a WJEC meeting, but could benefit from materials created outside the congresses and made available to all and from special virtual sessions that bring the WJEC ethic to wider audiences more frequently. While still an informal network, the World Journalism Education movement is moving forward aggressively as a vital global voice of journalism education.

\section{References:}

$5^{\text {th }}$ World Journalism Education Congress - teaching journalism during our disruptive age. Retrieved from https://www.wjec.paris.

Adam. G. S. (2001). The education of journalists. Journalism, 2(3), 315-339. 
Asia Research News. (2007). World Journalism Education Congress (WJEC). Retrieved from https://www.asiaresearchnews.com/html/calendar.php/eid/1510/cid/2/research/peopl e/administrator account/world journalism education congress \%28wjec\%29.html

Baines, D. (2017). Global journalism education in the $21^{\text {st }}$ century: Challenges and innovations "an invaluable resource." Retrieved from https://ajeuk.org/global-journalism-educationin-the-21st-century-challenges-and-innovations-an-invaluable-resource/

Bizcommunity. (2010). WJEC 2010 launched today. Retrieved from https://www.bizcommunity.africa/Article/410/15/49666.html

Carey, J. W. 1999. In defense of public journalism. In T. L. Glasser (Ed.), The Idea of Public Journalism (pp. 49-66). New York, NY: The Guilford Press.

Chang, T. K., \&Tai, Z. (2005). Mass communication research and the invisible college revisited: The changing landscape and emerging fronts in journalism-related studies. Journalism and Mass Communication Quarterly, 82(3), 672-694.

Claussen, D. (2017). Book review: Global journalism education in the $21^{\text {st }}$ century: Challenges and innovations. Journalism \& Mass Communication Educator, 73(1). Retrieved from https://www.researchgate.net/publication/321454115 Book Review Global Journalis $\underline{m}$ Education in the 21st Century Challenges and Innovations by Robyn S Goodm an and Elanie Steyn edsGoodmanRobyn SSteynElanie eds Global Journalism Educa tion in the 21st Cent

Deuze, M. (2017). On media and entrepreneurship as ways of being in the world: A challenge to journalism education. In R. S. Goodman \& E. Steyn (Eds.), Global journalism education in the $21^{\text {st }}$ century: Challenges and innovations (307-326). Austin, TX: Knight Center for Journalism in the Americas.

Fidalgo, J. (2018). Book review: Global journalism education in the $21^{\text {st }}$ century: challenges and innovations. European Journal of Communication, 33(5), 564-573.

Foote, J. (2007). World Journalism Education Congress: Its importance to ASJMC administrators. ASJMC Insights, 4-7, Fall.

Foote, J. S. (2008). World Journalism Education Congress. Journalism Studies, 9 (1), 132-138. https://doi.org/10.1080/14616700701768311.

Foote, J. S. (2006). Remarks to Deans Conference on Journalism Education, Shanghai, China, May 21, 2006.

Foote, J. S. (2011). WJEC highlights development of journalism around the world. ASJMC Insights, 8-9.

Goodman, R. S. (2007). WJEC syndicate reports: Eight approaches to improving journalism education worldwide. ASJMC Insights, 11-18, Fall.

Goodman, R. S. (2011). World Journalism Congress finds numerous issues of international scope. ASJMC Insights, 18-27, Spring. 
Goodman R. S. (2014). World Journalism Education Congress explores methods for renewing journalism through education. ASJMC Insights, 26-36, Spring.

Goodman, R. S. (2017a). Global journalism education: Accelerating forward, coasting, or losing ground? In R. S. Goodman \& E. Steyn (Eds.), Global journalism education in the $21^{\text {st }}$ century: Challenges and innovations (pp. 1-13). Austin, TX: Knight Center for Journalism in the Americas.

Goodman, R. S. (2017b). Global journalism education moving forward: Its state of mind, pursuit of truth, and support of civic life. Global journalism education in the $21^{\text {st }}$ century: Challenges and innovations (pp. 449-455). Austin, TX: Knight Center for Journalism in the Americas.

Goodman R. S. (2017c). World Journalism Education Congress offers recommendations for building identity and integrity in journalism education. ASJMC Insights, 12-18, Fall.

Goodman, R. S. (2020). WJEC's Paris syndicate program: Discussions advance global journalism education. Journalism \& Mass Communication Educator, 75(1), 3-8. Retrieved from https://journals.sagepub.com/doi/10.1177/1077695820901940

Goodman, R. S. \& Steyn, E. (2017). Preface. The backstory: It took a global village - Origins, development and production. In: R. S. Goodman \& E. Steyn (Eds.) (2017). Global journalism education in the $21^{\text {st }}$ century: Challenges and innovations. Austin, TX: Knight Center for Journalism in the Americas, pp. vii-x.

Goodman, R. S., \& Steyn, E. (Eds.). (2017). Global journalism education in the $21^{\text {st }}$ century: Challenges and innovations. Austin, TX: Knight Center for Journalism in the Americas.

International Program for the Development of Communication. (2020). Proceedings of the $32^{\text {nd }}$ session of the Intergovernmental Council. (Item 13, 25-26 November). Unesdoc Digital Library.

PND. (2010). World Journalism Education Census. Retrieved from https://philanthropynewsdigest.org/connections/world-journalism-education-census

Pulitzer, J. (1904). The college of journalism. The North American Review, 178(570), 641-680.

Rhodes University. (2010). World Journalism Education Congress comes to Rhodes. Retrieved from https://www.ru.ac.za/latestnews/archives/2010/2010-05-271409.html

Rupar, V. (2016). Identity and integrity in journalism education worldwide. Journalism and Mass Communication Educator, 71(3), 295-296.

Rupar, V. (2017). (Ed.). Themes and critical debates in contemporary journalism. Newcastle upon Tyne, UK: Cambridge Scholars Publishing.

Rupar, V. (2020). Personal correspondence. (23/12/20).

Self, C. C. (2007). Conducting an international census of journalism Education. ASJMC Insights, 7-10, Fall.

UNESCO. (2019). Series on journalism education. Retrieved from https://en.unesco.org/unescoseries-on-journalism-education 
WJEC Paris 2019. (2019). Syndicates recommendations. Retrieved from https://www.wjec.paris/syndicates-program/

WJEC. (2016). Syndicate programming. Retrieved from http://test.imran.oucreate.com/wjecsyndicates.htm

WJEC. (2019). What is WJEC? Retrieved from https://www.wjec.paris/about-wjec/

WJEC. (2020). Research on journalistic roles. Retrieved from https://wjec.net/?p=32195

World Journalism Education Council (2021). Declaration of Principles of Journalism Education. Retrieved from https://wjec.net/?page id=32108.

World Journalism Education Council (2021). Paris Declaration of Journalism Freedom. Retrieved from https://wjec.net/?page id=321.

World Journalism Education Council (2021). WJEC Charter. Retrieved from https://wjec.net/?page id=197.

World Journalism Education Council. (2007). Declaration of Principles. Retrieved from https://wjec.net/?page id=32108.

World Journalism Education Council. (2019). Declaration on Freedom of Journalism Education. Retrieved from https://www.wjec.paris/paris-declaration-on-freedom-of-journalismeducation/\#

Worlds of Journalism. (2020). Networking journalism research. Retrieved from https://worldsofjournalism.org/\#1568276757982-1b7305f0-8378

\section{Table 1: World Journalism Education Council Members 2007}

African Council on Communication Education (ACCE)

Arab-US Association of Communication Educations (AUSACE)

Asian Media Information Centre (AMIC)

Association for Education in Journalism and Mass Communication (AEJMC)

Association for Journalism Education (AJE) (UK)

Association of Schools of Journalism and Mass Communication (ASJMC)

Brazilian Society of Interdisciplinary Studies in Communication-Intercom

Broadcast Education Association (BEA)

Canadian Committee for Education in Journalism (CCEJ)

Chinese Communication Association (US-based)

Chinese Journalism Education Association

European Journalism Training Association (EJTA)

International Association of Media and Communication Research (IAMCR)

Israel Communication Association

Japan Society for Studies in Journalism and Mass Communication (JSSJMC)

Journalism Division, International Communication Association (ICA)

Journalism Education Association (Australia and New Zealand) 


\author{
Journet \\ Korean Society for Journalism and Communication Studies \\ Latin American Association of Communication Researchers (ALAIC) \\ Latin American Federation of Social Communication Schools (FELAFACS) \\ Nigerian Association of Journalism and Mass Communication Teachers \\ Philippine Association of Communication Education (PACE) \\ Russian Association for Education in Journalism \\ Russian Association for Film and Media Education \\ Saudi Association for Media and Communication \\ South African Communication Association \\ Trans-African Council for Communication (Tracce)
}

